\title{
Tuberculosis, AIDS and tuberculosis-AIDS co-infection in a large city
}

\author{
Nanci Michele Saita ${ }^{1}$ \\ Helenice Bosco de Oliveira²
}

\begin{abstract}
This study aimed to analyze the incidence of tuberculosis (TB), AIDS and tuberculosisAIDS co-infection in the municipality of Campinas, in the state of São Paulo, Brazil, in the period 2001 - 2009. A historical trend study, it uses secondary data from the Tuberculosis Surveillance Database of the University of Campinas (UNICAMP) and the São Paulo State STD-AIDS Center of Excellence and Training. It included new cases of TB, AIDS, and of tuberculosis-AIDS reported in the municipality of Campinas. A decrease in cases of TB until 2007 was observed, with an increase in 2008 and 2009. There was a general reduction in AIDS from 2007, but with an increase among men aged 60 or over, in the years 2007 to 2009. For tuberculosis-AIDS co-infection, the tendency was to reduce. The proportion of HIV tests not undertaken, among patients with tuberculosis, was high (27.5\%). This scenario shows the need for integration of the databanks into the planning and control activities.
\end{abstract}

Descriptors: Incidence; Tuberculosis; HIV.

\footnotetext{
${ }^{1}$ Master's student, Universidade Estadual de Campinas, Brazil.

2 PhD, Professor, Universidade Estadual de Campinas, Brazil.
} 


\section{Tuberculose, AIDS e coinfecção tuberculose-AIDS em cidade de grande porte}

Este estudo objetivou analisar as incidências da tuberculose (TB), AIDS e coinfecção TB-AIDS no município de Campinas, SP, Brasil no período de 2001 a 2009. Trata-se de estudo de tendência histórica, em que se utilizaram dados secundários do Banco de Dados em Vigilância da Tuberculose-Unicamp e do Centro de Referência e Treinamento DST-AIDS do Estado de São Paulo. Foram incluídos casos novos de TB, de AIDS e da coinfecção TB-AIDS notificados pelo município de Campinas. Observou-se decréscimo dos casos de TB até 2007, com aumento em 2008 e 2009. Na AIDS ocorreu redução geral a partir de 2007, mas com aumento entre os homens com 60 anos e mais, entre os anos 2007 e 2009. Para a coinfecção TB-AIDS, a tendência foi de redução. A proporção de testes anti-HIV não realizados, entre pacientes com tuberculose, foi elevada $(27,5 \%)$. Esse cenário revela a necessidade de integração dos bancos de dados nas atividades de planejamento e controle.

Descritores: Incidência; Tuberculose; HIV.

\section{Tuberculosis, SIDA y co-infección SIDA-tuberculosis en una gran ciudad}

Esta investigación tuvo como objetivo analizar la incidencia de tuberculosis (TBC), SIDA y el co-infección SIDA-TB en Campinas-SP-Brasil, 2001-2009. Se trata de un estudio de la tendencia histórica con datos de la Base de Datos de Monitoreo de TBC-UNICAMP y del sitio web del Centro de Referencia en SIDA de São Paulo. Se incluyeron los casos nuevos de TBC, SIDA y co-infección SIDA-TBC registrados a cada año en Campinas. Se observó disminución de casos de tuberculosis en 2007, con aumento en 2008-2009. El SIDA se produjo en la reducción global a partir de 2007, pero aumentan entre los hombres mayores de 60 años, en los años 2007-2009. Para la co-infección TB-VIH la tendencia de reducción. La proporción de exámenes VIH no realizados en pacientes con TBC fue alta $(27,5 \%)$. Este escenario pone de manifiesto la necesidad de integración de las bases de datos de TBC y SIDA para las actividades de planificación y control.

Descriptores: Incidencia; Tuberculosis; VIH.

\section{Introduction}

In 2010 the incidence coefficient (IC) for tuberculosis (TB), worldwide, was 128 per 100,000 persons ${ }^{(1)}$. Brazil, with an incidence of 43 cases per 100,000 in 2010, is in $19^{\text {th }}$ place among the 22 countries which reported $80 \%$ of cases of $\mathrm{TB}^{(1)}$.

The State of São Paulo recorded 19,024 cases in 2010, of which 16,406 were identified as new ${ }^{(2)}$. The municipality of Campinas presented an IC of 26.4/100,000 inhabitants in 2010(3).

Despite advances in the detection of new cases, in the introduction of powerful medication, and in the prevention of millions of deaths, the incidence of TB did not decline as expected(4).
Biological, social and environmental determinants have long been recognized as risk factors for infection and falling ill with $\mathrm{TB}^{(5)}$. HIV is one of these factors, responsible for high morbidity and mortality. It has the heaviest impact on TB incidence, modifying its clinical presentation, the duration of treatment it requires, its resistance to medication, and its epidemiological tendency. Poverty, too, is clearly associated with $\mathrm{TB}^{(6-7)}$, underlying the other risk factors; this relationship, however, is often mitigated in multivariate models which include more proximate determinants ${ }^{(5)}$.

The variations in the tendency of TB, AIDS and TBAIDS co-infection may occur between Brazilian states 
and cities due to the different regional characteristics and to the different levels of health planning and health care $^{(8-9)}$. The municipality of Campinas, in 2010, was among the five cities in the State of São Paulo which reported the most cases of $\operatorname{TB}^{(2)}$ and $\operatorname{AIDS}^{(10)}$.

The current reality of the two diseases strengthens the need for surveillance of the cases reported, which would permit verification of the scale of TB-AIDS comorbidity and the guidance of control actions, optimizing the use of the available resources.

As part of the global strategy of reducing morbiditymortality from TB, the World Health Organization (W.H.O) established targets - not only of detecting $70 \%$ of new cases and achieving an $85 \%$ success rate in treatment for TB, but also of implementing actions aiming to reduce prevalence and mortality by $50 \%$ by 2015 compared to 1990, and of eliminating TB as a public health problem by $2050^{(11-12)}$.

To achieve these goals, it is necessary to evaluate and monitor the actions, using local data collected from the epidemiological surveillance system. This being so, this study aimed to analyze the incidence of cases of TB, of AIDS, and of TB-AIDS co-infection, in the municipality of Campinas, between 2001 and 2009.

\section{Methods}

A historical trend study was undertaken, with annual distribution of the incidence of TB, AIDS, and TBAIDS co-infection, in the municipality of Campinas in the state of São Paulo, for the period 2001 - 2009.

Campinas is considered one of the state of São Paulo's industrial and technological centers and has the characteristic of attracting patients from neighboring municipalities in search of treatment. These include people with TB and AIDS, who are frequently diagnosed in the city. According to the Brazilian Institute for Geography and Statistics (BIGS), in 2010, Campinas had $1,024,912$ inhabitants.

The study included new cases of TB and AIDS which occurred in patients resident in Campinas and which were notified there. Individuals who were resident in other municipalities were excluded, as were patients in prison.

Information about the number of cases of TB and of TB-AIDS co-infection among new cases of TB were obtained from the TB Surveillance Database of the Faculty of Medical Sciences (FMS) of the University of Campinas (UNICAMP), which uses official notifications, laboratory data and mortality data. The notifications were verified in the Ministry of Health's Case Registry Database (SINAN, in Portuguese), in the years 2001 - 2006. From 2007, the São Paulo State Health Secretariat's TB-WEB system was used instead.

The TB Surveillance Database has been a continuous activity of the Faculty of Medical Sciences at UNICAMP since 1993, and the correction and purification of the records are carried out based on the patient's name, the name of the patient's mother, and the patient's date of birth. The notification registers for cases of TB - like the filling out of the items in the complementary tests previously carried out, and the closing of cases- are followed up on a weekly basis via the TB-WEB system, so as to avoid duplicating records. Information about TB-AIDS co-infection was extracted from the data fields referring to the associated illnesses and to the result of the HIV test.

The website of the Center of Excellence and Training in STD/AIDS of the State of São Paulo was used for obtaining data on AIDS. The databanks TABNET (adult) and TABNET (child) were used to ascertain the number of cases for each year studied. It was not possible to research the notification forms directly.

For the study of the historical series for TB, AIDS and TB-AIDS co-infection in the municipality, their Incidence Coefficients (IC) were calculated for the period 2001 - 2009. For each series, the numerator was made up from the new cases of TB, AIDS and TBAIDS, respectively, among residents of Campinas. The populational data used in the IC's denominator was from the Brazilian Institute for Geography and Statistics (IBGE). The coefficients were standardized based on the age distribution of the population in the 2000 Census.

The coefficients' tendencies were represented in tables, with regular intervals of one calendar year, and the calculation of moving averages. The moving average is a non-parametric method which has the purpose of smooth out the series when this varies as a result of time. The series was transformed through moving averages of order three to make it stationary and with toned-down values.

Further, the behavior of each temporal series was checked using the LOWESS (Locally-Weighted Regression Scatterplot Smoothing) method, which is a technique for adjusting curves based on locally-weighted regression or first-degree polynomial regression (non-parametric method). As the series extended over nine years, a small number for the adjustment, the moving averages were considered more suited than the LOWESS method.

In addition to the visualization of the smoothingout of the historical series, the proportion of the number 
of cases involving TB-AIDS co-infection among the new cases of TB reported was also verified. The distribution of cases of TB and AIDS was plotted, according to sex and age range. The proportions of the clinical forms of TB pulmonary and extra-pulmonary - were also calculated, according to the carrying out of the HIV test among the patients with TB. Due to shortcomings in the filling out of the TB notification form, variables such as level of schooling, occupation and other comorbidities were not studied, compromising the undertaking of multivariate analyses. A different data collection instrument would be necessary for studying factors which could alter the historical trend of the diseases presented.

Electronic spreadsheets and a statistical package were used for statistical procedures.

This study was approved by the Research Ethics Committee of the Faculty of Medical Sciences of the
State University of Campinas (UNICAMP), under Verdict $n^{\circ} 413 / 2006$ and was given authorization for the collection of data.

\section{Results}

In the period 2001 - 2009, notification was received of 2876 patients with TB, 2619 with AIDS and 512 with the co-infection. In Table 1 , one may observe a higher CI for TB in 2001 (with 39.61/100,000 inhabitants) followed by a decrease until 2007, and a rise in 2008 and 2009.

For AIDS, the highest IC was in 2006, with $40.98 / 100,000$ inhabitants. For the cases of coinfection, a decrease was ascertained during the period studied. Table 1 also shows that among the TB cases, the proportion of co-infected individuals varied between $23.1 \%$ (in 2002) and $13.8 \%$ (in 2009).

Table 1 - Number of cases, incidence coefficients, variation of the number of cases of TB, AIDS and TB-AIDS coinfection and the proportion of cases of TB-AIDS Campinas, São Paulo, Brazil, 2001-2009

\begin{tabular}{|c|c|c|c|c|c|c|c|c|c|c|c|}
\hline \multirow[t]{2}{*}{ Year } & \multirow[t]{2}{*}{ Pop. } & \multicolumn{3}{|c|}{$\begin{array}{c}\text { Tuberculosis } \\
n=2.876\end{array}$} & \multicolumn{3}{|c|}{$\begin{array}{c}\text { AIDS } \\
n=2.619\end{array}$} & \multicolumn{3}{|c|}{$\begin{array}{c}\text { TB-AIDS } \\
\mathrm{n}=512\end{array}$} & \multirow[t]{2}{*}{ TB-AIDS (\%) } \\
\hline & & $n^{\circ}$ & IC & $\operatorname{Var}(\%)$ & $n^{\circ}$ & IC & $\operatorname{Var}(\%)$ & $n^{\circ}$ & IC & $\operatorname{Var}(\%)$ & \\
\hline 2001 & 979414 & 388 & 39.61 & & 232 & 23.68 & & 85 & 8.67 & & 22.0 \\
\hline 2002 & 991893 & 385 & 38.81 & -2.0 & 285 & 28.73 & +21.3 & 89 & 8.97 & +3.5 & 23.1 \\
\hline 2003 & 1003597 & 327 & 32.58 & -16.1 & 377 & 37.56 & +30.7 & 63 & 6.27 & -30.1 & 19.3 \\
\hline 2004 & 1016236 & 300 & 29.52 & -9.4 & 232 & 22.82 & -39.2 & 46 & 4.52 & -27.9 & 15.3 \\
\hline 2005 & 1028599 & 314 & 30.52 & +3.4 & 348 & 33.83 & +48.2 & 47 & 4.56 & +0.9 & 15.0 \\
\hline 2006 & 1039397 & 297 & 28.57 & -6.4 & 426 & 40.98 & +21.1 & 47 & 4.52 & 0 & 15.8 \\
\hline 2007 & 1050299 & 264 & 25.13 & -12.0 & 281 & 26.75 & -34.7 & 44 & 4.18 & -7.5 & 16.7 \\
\hline 2008 & 1061316 & 296 & 27.88 & +10.9 & 219 & 20.63 & -22.9 & 49 & 4.61 & +10.3 & 16.5 \\
\hline 2009 & 1072418 & 305 & 28.44 & +2.0 & 219 & 20.42 & -0.97 & 42 & 3.91 & -15.2 & 13.8 \\
\hline
\end{tabular}

Pop $=$ Population

$\mathrm{N}^{\circ}=$ number of cases

IC=Incidence Coefficient

Var $=$ Variation

Table 2 presents the standardized coefficients and moving averages for TB, AIDS and TB-AIDS co-infection.
Comparison of the raw and standardized coefficients showed a small difference between the two.

Table 2 - Standardized coefficients and moving averages for TB, AIDS, and TB-AIDS co-infection. Campinas, São Paulo, Brazil, 2001-2009

\begin{tabular}{|c|c|c|c|c|c|c|}
\hline \multirow{2}{*}{ Year } & \multicolumn{2}{|c|}{$\begin{array}{c}\text { Tuberculosis } \\
n=2.876\end{array}$} & \multicolumn{2}{|c|}{$\begin{array}{c}\text { AIDS } \\
n=2.619\end{array}$} & \multicolumn{2}{|c|}{$\begin{array}{c}\text { TB-AIDS } \\
n=512\end{array}$} \\
\hline & SC & Moving Average & sc & Moving Average & sc & Moving Average \\
\hline 2001 & 40.07 & & 23.96 & & 8.77 & \\
\hline 2002 & 39.76 & 37.86 & 29.43 & 29.99 & 9.19 & 8.15 \\
\hline 2003 & 33.77 & 34.83 & 38.93 & 29.70 & 6.50 & 6.81 \\
\hline 2004 & 30.98 & 32.39 & 23.96 & 31.40 & 4.75 & 5.36 \\
\hline 2005 & 32.43 & 31.36 & 35.94 & 32.54 & 4.85 & 4.81 \\
\hline
\end{tabular}


Table 2 - (continuation)

\begin{tabular}{|c|c|c|c|c|c|c|}
\hline \multirow{2}{*}{ Year } & \multicolumn{2}{|c|}{$\begin{array}{c}\text { Tuberculosis } \\
\mathrm{n}=\mathbf{2 . 8 7 6}\end{array}$} & \multicolumn{2}{|c|}{$\begin{array}{c}\text { AIDS } \\
n=2.619\end{array}$} & \multicolumn{2}{|c|}{$\begin{array}{c}\text { TB-AIDS } \\
n=512\end{array}$} \\
\hline & sc & Moving Average & sc & Moving Average & sc & Moving Average \\
\hline 2006 & 30.67 & 30.12 & 44.00 & 33.85 & 4.85 & 4.74 \\
\hline 2007 & 27.26 & 29.50 & 29.02 & 29.45 & 4.54 & 4.81 \\
\hline 2008 & 30.57 & 29.77 & 22.62 & 22.60 & 5.06 & 4.64 \\
\hline 2009 & 31.50 & & 22.62 & & 4.33 & \\
\hline
\end{tabular}

$\mathrm{SC}=$ standardized coefficient

Between 2001 and 2009 notification was received of 941 female patients with TB and 1935 male patients with TB (Table 3). Among women, the higher incidences predominated in the age range '60 years and over', while among men the higher ICs were observed in the age range 40 - 59. The ratio between the male/female sexes (M/F) varied from 1.7 in 2005 to 2.3 in 2009 (data not presented in the tables).

In relation to AIDS, 896 new cases were notified among women, and 1722 among men (Table 3). There was practically no variation in the ratio among men, with 2.4 in 2001 and 2.5 in 2009 (data not presented in the tables). For both sexes, the highest incidences were between 20 and 39 years of age. In the years 2007 2009, an increase was observed in the incidence among men aged 60 or over.

2431 patients were diagnosed with pulmonary TB, and 445 with extra-pulmonary TB. The number of HIV tests not carried out was high. (Table 4).

Table 3 - Incidence coefficients for TB and AIDS, according to sex and age range. Campinas, SP, Brazil, 2001-2009

\begin{tabular}{|c|c|c|c|c|c|c|c|c|c|c|}
\hline \multicolumn{11}{|c|}{ Women } \\
\hline \multirow{2}{*}{ Year } & \multicolumn{5}{|c|}{ Tuberculosis $(n=932)$} & \multicolumn{5}{|c|}{ AIDS $(n=896)$} \\
\hline & $0-9$ & $10-19$ & $20-39$ & $40-59$ & $60 \mathrm{e}+$ & $0-9$ & $10-19$ & $20-39$ & $40-59$ & $60 \mathrm{e}+$ \\
\hline 2001 & 18.64 & 12.61 & 37.84 & 30.23 & 18.84 & 1.33 & 1.14 & 26.95 & 14.22 & 5.65 \\
\hline 2002 & 7.84 & 10.17 & 30.02 & 27.34 & 35.70 & 0 & 4.52 & 37.38 & 15.87 & 0 \\
\hline 2003 & 3.85 & 11.13 & 35.84 & 15.79 & 20.70 & 2.56 & 1.11 & 48.72 & 50.90 & 7.52 \\
\hline 2004 & 5.04 & 13.18 & 21.55 & 25.16 & 33.64 & 6.31 & 1.09 & 32.05 & 19.08 & 5.60 \\
\hline 2005 & 12.40 & 13.00 & 19.10 & 28.39 & 48.46 & 14.88 & 3.25 & 44.22 & 23.23 & 5.59 \\
\hline 2006 & 7.33 & 10.70 & 19.44 & 17.94 & 26.03 & 0 & 2.14 & 47.00 & 39.30 & 9.29 \\
\hline 2007 & 8.43 & 6.34 & 21.92 & 18.65 & 12.98 & 2.40 & 2.11 & 34.75 & 28.82 & 7.41 \\
\hline 2008 & 8.33 & 7.30 & 20.66 & 20.20 & 33.33 & 2.38 & 0 & 20.13 & 18.52 & 5.55 \\
\hline 2009 & 7.03 & 9.28 & 21.99 & 20.85 & 14.74 & 2.34 & 1.03 & 19.37 & 15.01 & 5.53 \\
\hline \multicolumn{11}{|c|}{ Men } \\
\hline \multirow{2}{*}{ Year } & \multicolumn{5}{|c|}{ Tuberculosis $(n=1910)$} & \multicolumn{5}{|c|}{ AIDS (n=1722) } \\
\hline & $0-9$ & $10-19$ & $20-39$ & $40-59$ & $60 \mathrm{e}+$ & $0-9$ & $10-19$ & $20-39$ & $40-59$ & $60 \mathrm{e}+$ \\
\hline 2001 & 12.84 & 14.83 & 65.97 & 91.67 & 59.97 & 1.28 & 3.42 & 61.26 & 48.76 & 14.99 \\
\hline 2002 & 8.83 & 13.50 & 70.91 & 91.75 & 72.15 & 0 & 0 & 78.47 & 57.95 & 4.97 \\
\hline 2003 & 6.19 & 6.65 & 52.14 & 76.25 & 66.49 & 3.71 & 1.10 & 78.50 & 77.20 & 7.38 \\
\hline 2004 & 6.08 & 7.65 & 48.67 & 70.09 & 49.34 & 1.21 & 0 & 51.50 & 43.57 & 12.33 \\
\hline 2005 & 0 & 11.85 & 50.83 & 62.84 & 71.21 & 7.17 & 3.23 & 81.55 & 56.27 & 14.73 \\
\hline 2006 & 12.96 & 12.78 & 43.07 & 78.12 & 58.72 & 7.07 & 0 & 105.48 & 79.98 & 7.34 \\
\hline 2007 & 4.64 & 7.36 & 38.78 & 65.43 & 48.72 & 1.16 & 2.10 & 63.36 & 46.08 & 12.18 \\
\hline 2008 & 5.74 & 12.45 & 45.90 & 71.77 & 38.53 & 1.14 & 2.07 & 54.54 & 39.06 & 16.86 \\
\hline 2009 & 5.65 & 7.18 & 39.52 & 84.99 & 82.04 & 2.26 & 0 & 52.87 & 44.30 & 19.30 \\
\hline
\end{tabular}

Tuberculosis: 34 patients of unknown age $(F=9$ and $M=25)$ between 2002-2009

AIDS: 01 patient of unknown age between 0-14 years of age in 2005 
Table 4 - Number of cases of, and incidence coefficient of TB, according to clinical presentation and results of HIV test. Campinas, São Paulo, Brazil, 2001-2009

\begin{tabular}{|c|c|c|c|c|c|c|c|c|c|c|c|c|c|c|}
\hline \multirow{3}{*}{ Year } & \multicolumn{7}{|c|}{$\begin{array}{c}\text { Pulmonary Form } \\
n=2.431\end{array}$} & \multicolumn{7}{|c|}{$\begin{array}{l}\text { Extra-pulmonary Form } \\
\qquad n=445\end{array}$} \\
\hline & \multicolumn{2}{|c|}{ HIV+ } & \multicolumn{2}{|c|}{ HIV- } & \multicolumn{2}{|c|}{ NU } & \multirow{2}{*}{$\begin{array}{l}\mathbf{T} \\
\mathrm{n}\end{array}$} & \multicolumn{2}{|c|}{ HIV+ } & \multicolumn{2}{|c|}{ HIV- } & \multicolumn{2}{|c|}{ NU } & \multirow{2}{*}{$\frac{\mathbf{T}}{\mathbf{n}}$} \\
\hline & $\mathrm{n}$ & $\%$ & $\mathbf{n}$ & $\%$ & $\mathrm{n}$ & $\%$ & & $n$ & $\%$ & $n$ & $\%$ & $n$ & $\%$ & \\
\hline 2001 & 68 & 20.2 & 129 & 38.3 & 140 & 41.5 & 337 & 17 & 33.3 & 21 & 41.2 & 13 & 25.5 & 51 \\
\hline 2002 & 64 & 20.0 & 158 & 49.4 & 98 & 30.6 & 320 & 25 & 38.5 & 21 & 32.3 & 19 & 29.2 & 65 \\
\hline 2003 & 51 & 17.9 & 164 & 57.7 & 69 & 24.3 & 284 & 12 & 27.9 & 27 & 62.8 & 4 & 9.3 & 43 \\
\hline 2004 & 36 & 14.7 & 121 & 49.4 & 88 & 35.9 & 245 & 10 & 18.2 & 29 & 52.7 & 16 & 29.1 & 55 \\
\hline 2005 & 34 & 12.9 & 167 & 63.5 & 62 & 23.6 & 263 & 13 & 25.5 & 32 & 62.7 & 6 & 11.8 & 51 \\
\hline 2006 & 30 & 12.2 & 137 & 55.9 & 78 & 31.8 & 245 & 17 & 32.7 & 26 & 50.0 & 9 & 17.3 & 52 \\
\hline 2007 & 34 & 14.9 & 132 & 57.9 & 62 & 27.2 & 228 & 10 & 27.8 & 20 & 55.6 & 6 & 16.7 & 36 \\
\hline 2008 & 36 & 14.3 & 167 & 66.3 & 49 & 19.4 & 252 & 13 & 29.5 & 20 & 45.5 & 11 & 25.0 & 44 \\
\hline 2009 & 32 & 12.5 & 175 & 68.1 & 50 & 19.5 & 257 & 10 & 20.8 & 26 & 54.2 & 12 & 25.0 & 48 \\
\hline
\end{tabular}

$\mathrm{NU}=$ not undertaken/unknown

$\mathrm{T}=$ total

\section{Discussion}

The change in the frequency of the diseases can be studied through the historical series and the number of years depends on the availability of data. The incidence is the indicator which, in the case of tuberculosis, responds most slowly to control measures. According to the W.H.O (1), even in countries which have the disease under control, incidence does not decline more than 5 $10 \%$ per year.

As the city of Campinas had an incidence rate of 26.4 per 100,000 inhabitants em $2010^{(3)}$, it is classified as having average incidence ${ }^{(1)}$. Table 1 shows that in the period 2001-2009 there was a reduction in the number of cases of TB and in its IC, although the category of low incidence - with less than 20 cases per 100,000 inhabitants - remains distant.

Both TB and AIDS present a higher number of cases among men, principally affecting the economicallyactive population. This data is similar to that from other municipalities in the state of São Paulo(2,10). Among men, the higher incidences of TB were in the age range 40 - 59 years old, followed by 60 years and over. Among women, the higher incidences alternated between 20 39 years old and 60 years and over. TB in the elderly is becoming more evident due to the ageing of the population, the increase in life expectancy, and the improvement in quality of life. The elderly are, however, subject to risk factors such as poverty, malnutrition and smoking, which favor the re-activation of the bacillus(13).

In relation to AIDS, in the state of São Paulo, the ratio between the male and female cases was 34:1 in 1985; a tendency to fall was shown until 1996, with 2:1 after which it remained stable until 2011(10). Campinas, with a ratio of 2.5:1, in 2009, was following the same tendency as the state of São Paulo having passed through important processes such as heterosexualization, decentralization, feminization and the pauperization ${ }^{(14)}$ of the epidemic.

AIDS, which used to be little-spread among the states of Brazil, has become wide-spread in the country over the years, principally in the Southwest and CenterWest regions, which have the largest number of cases reported in Brazil(14-15). On a small scale, Campinas may be considered as a space representing Brazil, and some factors deserve highlighting: it is near the city of São Paulo, facilitating both access to this metropolis and the other small cities around it ${ }^{(3)}$; it has a large number of favelas, while being at the same time a financial and business center, attracting investment. Besides this, the health area receives incentives, carries out research and has two teaching hospitals. This may explain the attractiveness that seeking treatment in Campinas has for ill people, who often fail to mention that they are from other cities.

In a study on the feminization and pauperization of AIDS in Campinas ${ }^{(16)}$, differences were observed in the ratio of men to women, which was heterogeneous in the city itself, higher in the city center and in the region north of the municipality, and with lower values in the outskirts, particularly in the region southwest of the municipality. The increase in the incidence of AIDS among men aged 60 or over in the years 2007 - 2009 may be attributed to factors linked to sexuality, such as a low understanding of risk, the practice of sex without condoms, and treatment for impotence. It is possible 
that sexuality has been promoted among the elderly due to the expectation of having more active lives. In addition, the impact of the introduction of anti-retroviral drugs has been to increase the prevalence of individuals living with AIDS.

The understanding of the presence of TB-AIDS co-infection is fundamental for the differentiated monitoring of patients, because this is related with lower compliance with treatment, higher drug resistance and higher mortality ${ }^{(17)}$. In this study, a decline was observed in the IC and in the proportion of co-infected patients with TB, from $23.1 \%$ in 2001 to $13.8 \%$ in 2009 , similar to that found in other municipalities in the state of São Paulo(18-19). It is worth emphasizing that the scale of the association between TB and AIDS may not be apparent, owing to problems related to under-reporting of these diseases, being estimated at $17.7 \%$ for Brazil(20).

Another piece of data which calls one's attention in this study, contributing to under-reporting, is the high proportion of HIV tests which are not carried out $(27.5 \%)$. Despite the occurrence of a reduction in the number of tests not carried out among patients with the pulmonary forms of TB during the period assessed (from $41.5 \%$ to $9.5 \%$ ), the same was not observed among the extrapulmonary forms. The fewer the TB patients who do the HIV test, the greater the uncertainty about the prevalence of co-infection(20).

It may be the case that many ill people fail to take this test, probably from fear about catching a stigmatizing disease such as AIDS, from lack of information about the test's importance, or due to the difficulties which health care professionals have in choosing the best approach in guiding people to take the HIV test and in the requesting of the test for ill people with TB. The doctor too may pay little attention to the result of the HIV test among patients diagnosed with TB, due to having to carry out too many consultations, to lack of supervision, or lack of updating.

The application of the HIV test should be guaranteed to all those who consent, but it must also be ensured that the results be entered into the information systems as soon as they become available(20).

The importance of evaluating secondary data, such as that used in the present study, must be emphasized. This data should be from different professionals who have distinct knowledge about the diseases and the different places in question, and be directed at improving the quality of the data and implementing interventions ${ }^{(21)}$, in parallel with the organization and maintenance of a fast and analytical surveillance system, capable of providing data which preventive actions could be based on, and for evaluating the situation and the co-infection tendency ${ }^{(22)}$. In 2004, 26\% of Brazilian municipalities of which $1 \%$ had populations equal to or over 20,000 - did not report cases of $\mathrm{TB}^{(23)}$.

One of this study's limitations was the small number of years of the series. With the exception of TB-AIDS co-infection after 2004, which showed a tendency to stabilize, relevant alterations were not detected. Factors for the possible alterations, such as changes in the diagnostic criteria or in treatment, were not observed in the period studied. In the case of AIDS, the drop in lethality had already been verified after the introduction of highly active antirretroviral therapy (HAART) at the end of $1996^{(17)}$. Factors linked to the notification of patients could explain the fluctuations observed in the series studied.

\section{Acknowledgements}

We are grateful to the state program for TB for the provision of TB-WEB for direct researching in the notification documentation. Also to the International Clinical, Operational and Health Services Research Training Awards Project for AIDS and Tuberculosis (ICOHRTA) - Brazil and the John Hopkins University for encouraging the research and for offering courses in the area of tuberculosis.

\section{Final Considerations}

The series' study, using secondary data, illustrated the tendency of the number of cases notified, as well as the epidemiological profile of TB, AIDS and the TBAIDS co-infection, allowing the detection of a decrease in cases of TB until 2007, with an increase in 2008 and 2009. In the case of AIDS, there was a general reduction from 2007, but with an increase among men aged 60 or over, in the years 2007 - 2009. For TB-AIDS co-infection, the tendency was one of reduction. This scenario shows the need for integration of information on TB and AIDS, with thorough filling-out of the records for TB-AIDS comorbidity, and in training which stimulates success in the communication of the different professionals involved, as support for planning and control actions.

In the face of the high proportion of HIV tests which are not carried out (27.5\%) among patients with tuberculosis, the importance must be emphasized of requesting the test and the guarantee that the results will be entered on the information systems. It is worth noting that nurses play an essential role in 
the development and concretization of this objective, when they undertake appropriate monitoring of notified cases, in the orientation of community health workers seeking greater effectiveness in case finding, in directly supervised treatment, and in the investigation of contacts between family members.

The interface of actions related to TB and AIDS occurs in the technical and political area. The present study's data strengthens the need for knowledge of the specific characteristics related to each region, with monitoring at a local level, by the TB and AIDS surveillance systems, contributing to a vision which completes the understanding of the national panorama relative to TB-AIDS co-infection.

\section{References}

1. World Health Organization. Global tuberculosis control: WHO report 2011. [acesso 22 ago 2011]. Disponível em: http://www.who.int/about/licensing/ copyright_form/en/index.html.

2. Secretaria do Estado de São Paulo (BR). Centro de Vigilância Epidemiológica. Série histórica 1998 a 2010 - Casos novos de tuberculose por forma clínica e faixa etária. [acesso 13 set 2011]. Disponível em: http://www. cve.saude.sp.gov.br/htm/tb/tb_num/tb_result.htm.

3. Prefeitura Municipal de Campinas (BR). Secretaria Municipal de Saúde de Campinas. Boletim Epidemiológico de Tuberculose - 2011. [acesso 17 ago 2011]. Disponível em: http://www.campinas.sp.gov.br.

4. Dye C, Lönnroth K, Jaramillo E, Williams BG, Raviglione $M$. Trends in tuberculosis incidence and their determinants in 134 countries. Bull World Health Organ. 2009;87:683-91.

5. Murray M, Oxlade $\mathrm{O}$, Lin $\mathrm{H}-\mathrm{H}$. Modeling social, environmental and biological determinants of tuberculosis. Int J Tuberc Lung Dis. 2011;15(6):S64-S70. 6. Janssens JP, Rieder HL. An ecological analysis of incidence of tuberculosis and per capita gross domestic product. Eur Respir J. 2008;32:1415-6

7. Oxlade O, Schwartzman K, Behr MA, Benedetti A, Pai M, Heymann J, Menzies D. Global tuberculosis trends: a reflection of changes in tuberculosis control or in population health? Int J Tuberc Lung Dis. 2009;13(10):1238-46.

8. Gonçalves MJF, Penna MLF. Morbidade por tuberculose e desempenho do programa de controle em municípios brasileiros 2001 - 2003. Rev Saúde Pública. 2007;41(supl1):95-103.
9. Grangeiro A, Escuder MML, Castilho EA. Magnitude e tendência da epidemia de Aids em municípios brasileiros de 2002-2006. Rev Saúde Pública. 2010;44(3):430-40 10. Secretaria do Estado de São Paulo (BR). Centro de Vigilância Epidemiológica. Boletim Epidemiológico CRT DST/Aids. Ano 27(1). 2010. [acesso 15 maio 2012]. Disponível em: http://www.crt.saude.sp.gov.br.

11. World Health Organization. The Global Plan to Stop TB, 2006-2015. Actions for life - towards a world free of tuberculosis. Geneva: WHO; 2006. (WHO/HTM/ STB/2006.35).

12. World Health Organization. The Stop TB Strategy: Building on and enhancing DOTS to meet the TB-related Millennium Development Goals. Geneva: WHO; 2006. WHO/HTM/TB/2006.368

13. Davies PDO. TB in the elderly in industrialised countries. Int J Tuberc Lung Dis. 2007;11:1157-9.

14. Brito AM, Castilho EA, Szwarcwald CL. AIDS e infecção pelo HIV no Brasil: uma epidemia multifacetada. Rev Soc Bras Med Trop. 2000;34(2):207-17.

15. Ministério da Saúde (BR). Boletim Epidemiológico DST-Aids 2010. [acesso 17 ago 2011]. Disponível em: http://www.aids.gov.br/sites/default/files/anexos/ publicacao/2010/

45974/vers_o_final_15923.pdf

16. Stephan C, Henn CA, Donalisio MR. Expressão geográfica da epidemia de Aids em Campinas, São Paulo, de 1980 a 2005. Rev Saúde Pública. 2010,44(5):812-9. 17. Oliveira HB, Marin-León L, Cardoso JC. Perfil de mortalidade de pacientes com tuberculose relacionada à comorbidade tuberculose-Aids. Rev Saúde Pública. 2004;38(4):503-10.

18. Santos MLSG, Ponce MAS, Vendramini SHF, Villa TCS, Santos NSGM, Wysocki AD, et al. A dimensão epidemiológica da co-infecção TB/HIV. Rev. Latino-Am. Enfermagem. 2009;17(5):683-8.

19. Secretaria do Estado da Saúde de São Paulo (BR). Coordenadoria de Controle de Doenças. Tuberculose no Estado de São Paulo. Indicadores de Morbimortalidade e Indicadores de Desempenho. Bol Epidemiol Paul. 2006;3,supl 4.

20. Carvalho CN, Dourado I, Bierrenbach AL. Subnotificação da comorbidade tuberculose e Aids: uma aplicação do método de linkage. Rev Saúde Pública. 2011;45(3):548-55.

21. Miranda AE, Golub JE, Lucena FF, Maciel EM, Gurgel MF, Dietze R. Tuberculosis and AIDS co-morbidity in Brasil: Linkage of the tuberculosis and AIDS databases. Braz J Infect Dis. 2009;13(2):137-41. 
22. Jamal LF, Moherdauí F. Tuberculose e infecção pelo HIV no Brasil: magnitude do problema e estratégias para o controle. Rev Saúde Pública. 2007;41(supl 1):104-10.

23. Bierrenbach AL, Gomes ABF, Noronha EF, Souza MFM. Incidência de tuberculose e taxa de cura, Brasil, 2000 a 2004. Rev Saúde Pública. 2007;41(supl1):24-33. 